\title{
Microbial Hydroxylation of Tedonodiol with Cultures of Aspergillus Niger
}

\author{
R. Carrizo Flores, L. Pous, C. E. Tonn, E. Guerreiro and O. S. Giordano \\ Química Orgánica - INTEQUI - CONICET - Facultad de Qca., Bioqca. y Fcia., UNSL, Chacabuco y \\ Pedernera. (5700). San Luis, República Argentina \\ E-mail: rcarrizo@unsl.edu.ar
}

\begin{abstract}
Microbial hydroxylation of tedonodiol, an eremophilane alcohol, was carried out with Aspergillus niger cultures, yielding the $2 \alpha$ - hydroxyderivative.
\end{abstract}

\section{Introduction}

Since 1986, we have performed a project enclose in a extraction of carbonyl $\alpha, \beta$-insaturated compounds from natural sources and chemical transformations of them, in order to provide metabolites to be tested as gastrointestinal citoprotective agents[1]. In this context we have carried out biotransformation reactions of tedonodiol, an eremophilane alcohol, isolated from Tessaria dodoneaefolia [2]. Several Aspergillus niger strains were used with this purpose.

\section{Experimental}

\section{Culture media}

Modified Czapek broth [3] was used for performed bioconversions assays, and agar Czapek was used to maintainning the strains.

\section{Strains}

Aspergillus niger ATCC 11394, Aspergillus niger Buenos Aires and a regional Aspergillus niger strain isolated from leaves of Artemisia douglassiana Besser.

\section{Culture conditions}

Biotransformations were carried out by two steps fermentation procedure [4]. Fermentations were performed in conical flasks $(3 \times 125 \mathrm{ml})$ with $25 \mathrm{ml}$ of culture medium, on shaken at 180 r.p.pm. and incubated at $28^{\circ} \mathrm{C}$. Substrate was dissolved in DMSO and added to $72 \mathrm{~h}$ old cultures ( final concentra- 
tion $1 \mathrm{mg} \cdot \mathrm{ml}^{-1}$ ). The process was continued for 7 days. Biotransformation product was recovered from the broth by liquid - liquid extraction with $\mathrm{Et}_{2} \mathrm{O}$. Extracts were concentrated, and the solid was purified by C.C. with $n$-hexane - EtOAc mixtures of increasing polarity.

\section{Results and Discussion}

Only the fermentation process carried out with Aspergillus niger Buenos Aires yield a more polar product than tedonodiol in the fraction $n$ - hexane - EtOAc $(20: 80)$. By the comparison of the sustrate and product ${ }^{1} \mathrm{H}$ - NMR spectra it was possible determinated that an $\alpha$-hydroxyl group incorporated on C-2 A new signal at $\delta 4.12 d d d\left(\mathrm{~J}_{1}=\mathrm{J}_{2}=2.9 \mathrm{~Hz}\right.$ y $\left.\mathrm{J}_{3}=3,8 \mathrm{~Hz}\right)$ corresponding to the new allylic oxygenated methine group, confirm this fact.
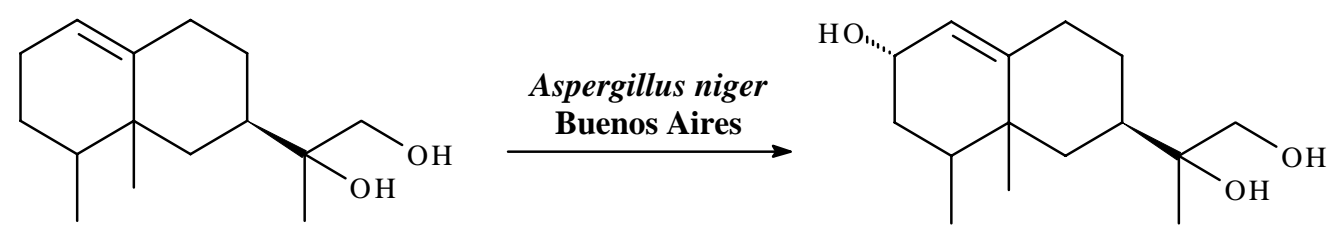

Usually, microbial hydroxylation shows high regioselectivity on molecules with activated positions [5], like tedonodiol C-2 allylic position.

Acknowledgements: This work was performed with support of CONICET and U.N.S.L. (Project 7301).

\section{References and Notes}

1. Rodriguez, A.M.; Enriz, R.D.; Santagata, L.; Jáuregui, E.; Pestchanker, M.; Giordano, O. Journal of Medicinal Chemistry 1997, 40, 1827.

2. Guerreiro, E.; Kavka, J.; Giordano, O.S. Anales de Asoc. Qca. Argentina 1979, 67, 119.

3. Pruna, B.R.; Bhattacharya, P.R. Applied Microbiology 1969, 10, 524.

4. Carreras, C.R.; Rodriguez, J.; Silva, H. J.; Rossomando, P.; Giordano, O.S.; Guerreiro, E. Phytochemistry 1996, 41, 473.

5. Carrizo, R.; Tonn, C.; Guerreiro, E. Natural Product Letters 1998, 12, 271. 